\title{
Muskmelon Cultivar Attractiveness to Striped Cucumber Beetle and Susceptibility to Bacterial Wilt
}

\author{
Ahmad Shah Mohammadi ${ }^{1}$ and Elizabeth T. Maynard ${ }^{2}$ \\ Department of Horticulture and Landscape Architecture, Purdue University, \\ 625 Agriculture Mall Drive, West Lafayette, IN 47907
}

\author{
Ricky E. Foster \\ Department of Entomology, Purdue University, 901 West State Street, West \\ Lafayette, IN 47907
}

Daniel S. Egel
Department of Botany and Plant Pathology, Purdue University, 4369 North
Purdue Road, Vincennes, IN 47591

Kevin T. McNamara

Department of Agricultural Economics, Purdue University, 403 West State Street, West Lafayette, IN 47907

Additional index words. Cucumis melo, cantaloupe, pest management, Erwinia tracheiphila, Acalymma vittatum

Abstract. Bacterial wilt of cucurbits, incited by Erwinia tracheiphila (E. F. Smith) and vectored by the striped cucumber beetle [Acalymma vittatum (F.)] (SCB), is a serious disease of muskmelon (Cucumis melo $\mathrm{L}$.). Cultivars differ in attractiveness to SCB and susceptibility to bacterial wilt, but no cultivar resistant to bacterial wilt has been introduced. In 2015 and 2016, replicated field plots of eight cultivars were grown at Lafayette, Wanatah, and Vincennes, IN, to identify differences in attractiveness to SCB and susceptibility to bacterial wilt. 'Savor' had significantly more beetle activity than 'Hales Best', 'Superstar', and 'Aphrodite' in three of six site-years, and more than 'Diplomat', 'Dream Dew', 'Athena', and 'Wrangler' in two site-years. Beetle activity for 'Athena', 'Superstar', and 'Wrangler' did not differ significantly from 'Aphrodite' for any site-year. Bacterial wilt severity was significantly greater for 'Diplomat' and 'Dream Dew' than for other cultivars in four site-years. 'Superstar' had the least disease in five site-years, but significantly less than 'Aphrodite', 'Athena', and 'Hales Best' in only one site-year. At one site, additional plots of each cultivar were populated with five SCBs per plant, and rowcovers were applied to keep the SCBs near the plants for 3 weeks. This resulted in similar beetle activity on all cultivars, but most disease in 'Dream Dew' and least in 'Superstar' and 'Athena'. Marketable yield was generally highest for 'Aphrodite', 'Superstar', and 'Athena' when plants were exposed to natural beetle populations. Overall, 'Savor' and 'Diplomat' were the most attractive to beetles, and 'Diplomat' and 'Dream Dew' were the most susceptible to bacterial wilt. 'Aphrodite', 'Athena', and 'Superstar' were less attractive to beetles and showed more tolerance to bacterial wilt in both 2015 and 2016.

Muskmelons (C. melo) are important crops grown throughout the world. The United States ranked seventh after China,

\footnotetext{
Received for publication 12 Jan. 2018. Accepted for publication 17 Apr. 2018.

This project was supported by funding from US AID under Agreement No. AID-306-A-00-11-00516, Grant No 105252.

We thank the staff of Purdue Agricultural Centers for their assistance with field work and data collection.

${ }^{1}$ Current address: Agriculture Faculty, Herat University, Daneshjoo Street, Herat, Afghanistan.

${ }^{2}$ Corresponding author. E-mail: emaynard@purdue. edu.

This is an open access article distributed under the CC BY-NC-ND license (http://creativecommons. org/licenses/by-nc-nd/4.0/).
}

Turkey, Iran, Egypt, India, and Kazakhstan in 2014, with total production of $7.7 \times 10^{5}$ metric tons (FAO, 2017; USDA-NASS, 2016). The per capita consumption of muskmelon in the United States was $3.8 \mathrm{~kg}$ in 2015 (USDA-ERS, 2016). The United States is a major importer of muskmelon from Latin America during the offseason from December through May (USDA-ERS, 2016).

The term muskmelon is used for both netted muskmelons (cantaloupes) (C. melo subsp. melo var. cantalupo) and honeydew melons ( $C$. melo subsp. melo var. inodorus) (USDA-NAL, 2017). Netted muskmelons in the United States market are primarily orange fleshed. Major growing regions in the western and eastern United States have led to development of "western" types characterized by heavier netting, more spherical shape, no sutures, and smaller size; and "eastern" types which have less dense netting and tend to be larger, more oblong, and with deeper sutures. Smaller quantities of specialty netted muskmelons are grown in the United States. These include green-fleshed, netted-rind "galia" types, and orange-fleshed, smallfruited $(1 \mathrm{~kg})$, lightly netted, green-sutured "charentais" types. Honeydew melons marketed in the United States are primarily green-fleshed with smooth rinds and represent $20 \%$ of the country's muskmelon production (USDA-NASS, 2016).

Striped cucumber beetle (A. vittatum) is the most serious insect pest of muskmelon in the eastern half of the United States (Foster et al., 2005). In the Midwest, SCBs overwinter as adults, emerge when temperatures reach 12 to $15^{\circ} \mathrm{C}$, and begin their search for cucurbit hosts. Volatiles produced by the plants attract SCBs to muskmelons initially, then male SCBs produce pheromones attracting more beetles (Metcalf and Lampman, 1989). SCBs feed on melon leaves, stems, flowers, and fruit, but are most important because they transmit E. tracheiphila, the bacterium that causes bacterial wilt. Bacterial wilt is a major disease of cucurbits in the United States (Latin, 1993; Smith, 1911). Bacteria are introduced to plants when cucumber beetles carrying E. tracheiphila in their gut feed on plants and leave behind frass containing the bacteria. SCB are the most common beetle species but sometimes spotted cucumber beetles (Diabrotica undecimpunctata howardii Barber) are involved. Plants become infected when bacteria enter through the feeding wounds. The bacteria multiply and block the plant xylem, restricting water and nutrient flow to distal parts of the plant; plants wilt and eventually die, and vines with bacterial wilt often fail to produce marketable fruit, resulting in economic loss (Rojas et al., 2015). Bacterial wilt can result in $10 \%$ to $75 \%$ loss of unprotected muskmelon plants (Brust and Foster, 1999).

To avoid bacterial wilt in muskmelon crops, growers must prevent SCBs from feeding on the plants (Foster et al., 2005). Current practices include timing of planting to avoid feeding by overwintered adult beetles, rowcovers to exclude beetles, trap crops, and insecticides.

Identifying cultivars resistant to the SCB, bacterial wilt, or both would simplify management and reduce reliance on insecticides, which often have undesirable effects on nontarget organisms, including natural enemies and pollinators. Resistance to bacterial wilt in cucurbits is known: watermelons rarely die from bacterial wilt, and squashes and pumpkins are less susceptible than muskmelons and cucumbers (Shapiro et al., 2014; Smith, 1911). Muskmelon cultivars differ in attractiveness to SCBs, as measured by the numbers of beetles found on plants, and the amount of beetle feeding they sustain, but no cultivar completely immune to beetle feeding has been identified (Brust and Rane, 1995). Brust and Rane (1995) showed that the incidence of bacterial wilt was correlated 
with beetle feeding injury on 10 cultivars. However, when they injected the bacterial wilt pathogen into seedlings mechanically, no difference in survival was detected among cultivars. By contrast, Reed and Stevenson (1985), who examined more than 185 cultivars, found that the cultivars differed in incidence and severity of the bacterial wilt when seedlings were inoculated with the pathogen mechanically, and also differed in mortality when plants were infected by natural populations of SCBs. Given these conflicting reports, it is not clear whether muskmelon cultivars differ in susceptibility to bacterial wilt only because they differ in attractiveness to SCBs, or whether there is genetic resistance to establishment or spread of the bacteria in the plants. Regardless of the mechanism, these authors concluded that the level of resistance they observed is not adequate for commercial production without additional control measures (Brust and Rane, 1995; Reed and Stevenson, 1985).

To develop resistant cultivars, a first step is to screen currently available cultivars to identify those most and least attractive to beetles, and those most and least susceptible to bacterial wilt. We hypothesized that currently available cultivars would differ in 1) attractiveness to SCBs and 2) susceptibility to bacterial wilt.

\section{Materials and Methods}

Field comparisons of muskmelon cultivars were carried out in 2015 and 2016 at three locations: Southwest Purdue Agricultural Center (SWPAC) near Vincennes, IN; Meigs Farm at Throckmorton Purdue Agricultural Center (TPAC) near Lafayette, IN; and Pinney Purdue Agricultural Center (PPAC), near Wanatah, IN. Median first and last frost dates are $12 \mathrm{Apr}$. and 21 Oct. for Vincennes, 21 Apr. and 15 Oct. for Lafayette, and 4 May and 4 Oct. for Wanatah (Midwestern Regional Climate Center, 2017). Eight commercially available cultivars of muskmelon, including both cantaloupe and honeydew, were planted between 13 and 21 Apr. in 72-cell black seedling flat trays filled with soilless growing media (SunGro Horticulture, Agawam, MA) and grown in greenhouses. Cultivars were selected to represent the following categories: 1) orange-fleshed hybrids, released between 1980 and 2008 ('Superstar', 'Athena', 'Aphrodite', and 'Wrangler'); 2) an open-pollinated cultivar available before 1927 ('Hales Best'); 3) specialty muskmelons including charentais ('Savor'), and galia ('Diplomat') types, and 4) honeydew ('Dream Dew'). Seeds were obtained from Harris Moran (Davis, CA: 'Superstar' and 'Dream Dew'), Johnny's Selected Seeds (Winslow, ME: 'Diplomat', 'Savor', and 'Wrangler'), Rupp Seeds (Wauseon, OH: 'Hales Best'), and Seedway (Elizabethtown, PA: 'Athena' and 'Aphrodite'). Seedlings were transplanted between 12 and 21 May to $0.66-\mathrm{m}$ wide raised beds covered with 1.2-m wide black plastic mulch and supplied with drip irrigation from tape with emitters at $30-\mathrm{cm}$ spacing. Fertility, disease, and weed management followed recommended practices for the region (Egel et al., 2014). Fungicide products were applied multiple times at recommended rates. All experiments were laid out in randomized completed block designs with four replications. The experimental unit was one plot of a cultivar. Details for each location are provided in Table 1.

In the main experiment, repeated both years at all three locations, natural populations of SCBs were allowed to feed on plants with no disturbance. No insecticide was applied in the main experiment in either year. A second experiment permitted assessment of differences in bacterial wilt severity when cultivars were exposed to similar numbers of beetles. In the second experiment, conducted only at TPAC, two additional plants per cultivar per replication were protected from natural beetle populations immediately after transplanting with a spun-bonded rowcover (17 $\mathrm{g} \cdot \mathrm{m}^{-2}$ and $1.8 \mathrm{~m}$ wide; Robert Marvel Plastic Mulch, Annaville, PA) supported by wire hoops. Beetles were collected from Silverthorne Farm, in Rossville, IN, and within hours five per plant (10 per plot) were released under the rowcover and left to feed for 3 weeks. Rowcovers were removed after 3 weeks to allow pollination. In 2015, natural populations of beetles were allowed to feed after rowcover removal and no insecticide was applied. In 2016, weekly applications of the insecticide lambda-cyhalothrin at $34 \mathrm{~g} \cdot \mathrm{ha}^{-1}$ (Warrior II; Syngenta, Basel, Switzerland) were made after rowcover removal to prevent subsequent beetle feeding.

Table 1. Plot size, plant population, and dates of planting; beetle counts, disease assessments, and harvest for four experiments

\begin{tabular}{|c|c|c|c|c|c|c|c|c|}
\hline & \multicolumn{2}{|c|}{ SWPAC } & \multicolumn{2}{|c|}{ TPAC } & \multicolumn{2}{|c|}{ PPAC } & \multicolumn{2}{|c|}{ TPAC restricted } \\
\hline & 2015 & 2016 & 2015 & 2016 & 2015 & 2016 & 2015 & 2016 \\
\hline Plot length (m) & 9.8 & 9.8 & 12.2 & 12.2 & 12.2 & 12.2 & 2.4 & 2.4 \\
\hline Row spacing (m) & 1.82 & 1.82 & 3.05 & 3.05 & 3.35 & 3.35 & 3.05 & 3.05 \\
\hline Plants per plot & 12 & 12 & 10 & 10 & 20 & 20 & 2 & 2 \\
\hline Seed date & 13 Apr. & 13 Apr. & 21 Apr. & 18 Apr. & 14 Apr. & 18 Apr. & 21 Apr. & 18 Apr. \\
\hline Growing media & \multicolumn{2}{|c|}{$\begin{array}{l}\text { Metro-Mix 360; SunGro } \\
\text { Horticulture }\end{array}$} & \multicolumn{2}{|c|}{$\begin{array}{l}\text { Redi-earth Plug \& Seedling } \\
\text { Mix with RESiLIENCETM }\end{array}$} & \multicolumn{2}{|c|}{$\begin{array}{l}\text { Sunshine \#1 Natural \& } \\
\text { Organic }\end{array}$} & \multicolumn{2}{|c|}{$\begin{array}{l}\text { Redi-earth Plug \& Seedling } \\
\text { Mix with RESiLIENCETM }\end{array}$} \\
\hline Transplant date & 13 May & 13 May & 21 May & 17 May & 14 May & 12 May & 21 May & 17 May \\
\hline Plastic mulch & $\begin{array}{r}0.020 \mathrm{mn} \\
\text { Ginega } \\
\text { Santa I }\end{array}$ & $\begin{array}{l}\text { degradable; } \\
\text { c Products, } \\
\text { CA }\end{array}$ & $\begin{array}{r}0.018 \mathrm{~mm} \\
\text { Mid So } \\
\text { Monro }\end{array}$ & $\begin{array}{l}\text { degradable; } \\
\text { rusion, }\end{array}$ & $\begin{array}{r}0.025 \mathrm{mr} \\
\text { FilmT } \\
\text { Allent }\end{array}$ & $\begin{array}{l}\text { ossed; } \\
\text { rp., } \\
\text { A }\end{array}$ & $\begin{array}{r}0.018 \mathrm{mi} \\
\text { Mid S }\end{array}$ & $\begin{array}{l}\text { odegradable; } \\
\text { trusion }\end{array}$ \\
\hline Drip tape & $\begin{array}{r}\text { T-Tape; } \\
\text { Techn } \\
\text { Marco }\end{array}$ & $\begin{array}{l}\text { San } \\
\text { eere Water }\end{array}$ & $\begin{array}{l}\text { AquaTrax } \\
\text { Compa }\end{array}$ & $\begin{array}{l}\text { Toro } \\
\text { omington, } \mathrm{MN}\end{array}$ & $\begin{array}{r}\text { Ro-drip; } \\
\text { San D }\end{array}$ & $\begin{array}{l}\text { Irrigation, } \\
\text { A }\end{array}$ & $\begin{array}{l}\text { AquaTra } \\
\text { Comp }\end{array}$ & Toro \\
\hline \multicolumn{9}{|l|}{$\begin{array}{l}\text { Fungicide } \\
\text { applications }\end{array}$} \\
\hline First & 10 June & 3 June & 30 June & 10 June & 21 July & 24 June & 30 June & 10 June \\
\hline Last & 21 July & 1 Aug. & 20 July & 29 July & 4 Aug. & 8 July & 20 July & 29 July \\
\hline$N$ & 5 & 7 & 4 & 5 & 3 & 2 & 4 & 5 \\
\hline Beetle counts & & & & & & & & None \\
\hline First & 20 May & 25 May & 6 June & 26 May & 25 June & 31 May & 22 June & \\
\hline Last & 1 July & 5 July & 10 July & 15 July & 6 Aug. & 14 July & 10 July & \\
\hline$N$ & 7 & 7 & 10 & 12 & 7 & 7 & 5 & \\
\hline \multicolumn{9}{|l|}{$\begin{array}{l}\text { Bacterial wilt } \\
\text { assessments }\end{array}$} \\
\hline First & 10 June & 21 June & 22 June & 24 June & 16 July & 23 June & 10 July & 17 June \\
\hline Last & 15 July & 20 July & 3 Aug & 29 July & 14 Aug. & 28 July & 3 Aug. & 3 Aug. \\
\hline$N$ & 6 & 5 & 7 & 7 & 5 & 6 & 4 & 4 \\
\hline \multicolumn{9}{|l|}{ Harvest dates } \\
\hline First & 13 July & 11 July & 31 July & 25 July & 10 Aug. & 28 July & 31 July & 25 July \\
\hline Last & 31 July & 5 Aug. & 13 Aug. & 17 Aug. & 3 Sept. & 13 Aug. & 10 Aug. & 17 Aug. \\
\hline$N$ & 9 & 10 & 5 & 9 & 8 & 4 & 4 & 9 \\
\hline
\end{tabular}

SWPAC $=$ Southwest Purdue Agricultural Center; TPAC $=$ Throckmorton/Meigs Purdue Agricultural Center; PPAC $=$ Pinney Purdue Agricultural Center; TPAC restricted $=$ Throckmorton/Meigs Purdue Agricultural Center, beetle populations restricted with rowcover. 
Cultivar attractiveness to beetles was assessed by counting the numbers of beetles on plants regularly during the growing season and then calculating "beetle days" to obtain a single response variable that combines density and duration of beetles. Counts began in the main experiment within a week of transplanting and continued weekly at SWPAC and PPAC and twice weekly at TPAC until harvest. Counts were made before noon and not during rain. Table 1 reports the date range and number of nonzero beetle counts, with the earliest date representing the first positive beetle count for each location. Beetle days were calculated using the following formula in a manner similar to that used to calculate mite days in tree fruit pest management (Stanyard et al., 1997):

$$
\text { Beetle days }=\sum_{i=1}^{n}\left(B_{i} \times D_{i}\right),
$$

where $i=$ observation dates, from 1 to $n ; B_{i}=$ number of beetles per plant at observation $i$; $D_{i}=$ number of days between observation $i$ and $i-1$; and $D_{1}=1$.

The severity of bacterial wilt was evaluated 1 week after transplanting and then every week until the second harvest. The presence of bacterial wilt in the trials was confirmed using the field diagnostic test described by Latin (1993). Symptoms were assessed visually by walking through each replication and rating each experimental unit (plot) using the Horsfall-Barratt scale for assessing disease (Horsfall and Barratt, 1945). Ratings were converted to percentage using the ELANCO tables (Redman et al., 1974). The area under the disease progress curve (AUDPC) was calculated from the percentage values using trapezoid integration (Shaner and Finney, 1977).

Mature fruit were harvested at 2- to 4-d intervals for a total of four to nine harvests depending on location and year (Table 1). Number and weight of marketable and cull fruit were recorded. Fruit were culled when they were too small (less than $1 \mathrm{~kg}$ or, for the small-fruited 'Savor', less than $12 \mathrm{~cm}$ in diameter), harvested from a plant infected with bacterial wilt, damaged by insects, infected with other diseases, or cracked.

Statistical significance of cultivar effects on beetle days, AUDPC, and marketable yield were evaluated using analysis of variance (ANOVA) followed by mean separation using Fisher's protected least significant difference with $\alpha=0.05$. Variances were not homogenous across years and locations and so each site-year was analyzed separately. The natural $\log$ of values for AUDPC (or AUDPC +1 for site-years where AUDPC = 0 for some experimental units), was analyzed to stabilize variances for SWPAC in 2015, PPAC in both years, and the second experiment at TPAC in 2016. For yield, cultivars with no yield were omitted from analysis for that site-year. When variances for yield were unequal for a site-year, log- and square-root transformations were evaluated, and squareroot transformations were found to stabilize variances. For those site-years, square-root transformed yield values were analyzed. Statistical analyses were performed with JMP Version 12.0 for MAC (SAS Institute, Cary, NC). Specific JMP procedures included "Fit Y by X" with test that the variances are equal and "Fit Model" using standard least squares, rep and cultivar as sources of variation, and "LSMeans Student's $t$ " options.

The relationship between AUDPC and beetle days across all years and locations, and the influence of cultivar on that relationship, was evaluated using ANOVA with AUDPC as the response, and beetle days, cultivar, and their interaction as sources of variation (JMP procedure "Fit Model" using standard least squares). This provides the significance of a regression of AUDPC vs. beetle days and also tests for the need for separate intercepts or slopes for the different cultivars.

\section{Results}

Beetle days. With the exception of PPAC in 2015, beetles began feeding on plants within 3 weeks of transplanting (Table 1). At PPAC in 2015, beetles were first observed $42 \mathrm{~d}$ after transplanting. At SWPAC, beetle days did not differ significantly among cultivars in 2015 (Table 2). In 2016, 'Savor' accumulated significantly more beetle days than other cultivars, followed by 'Diplomat'. 'Aphrodite' accumulated significantly fewer beetle days than those two cultivars.

At TPAC in 2015, 'Diplomat' accumulated significantly more beetle days than any other cultivar except 'Savor' (Table 2). 'Hales Best', 'Dream Dew', 'Aphrodite', and 'Superstar' accumulated significantly fewer beetle days than the others. In 2016, cultivars did not differ significantly in beetle day accumulation except for 'Dream Dew', which had fewer than the others.

At PPAC, beetle days did not differ significantly among cultivars in 2015 (Table 2). In 2016, 'Savor' and 'Dream Dew' accumulated significantly more beetle days than the other cultivars. 'Aphrodite' accumulated the fewest beetle days in 2016; significantly fewer than 'Hales Best', 'Diplomat', 'Savor', and 'Dream Dew'.

When beetle populations were limited to five per plant for 3 weeks after transplanting, beetle days did not differ significantly among cultivars after the rowcovers were removed in 2015 (Table 2). In 2016, the insecticide applied after rowcovers were removed reduced beetle populations so effectively that beetles were not encountered.

Area under disease progress curve. In both years at SWPAC, bacterial wilt was the most severe on 'Dream Dew' and 'Diplomat' (Table 3). In 2015, the disease was significantly less severe on all other cultivars. In 2016, 'Superstar' was the least severely affected, and together with 'Athena' and 'Aphrodite' had significantly less disease

Table 2. Beetle days values for eight muskmelon cultivars exposed to natural or restricted populations of striped cucumber beetles.

\begin{tabular}{|c|c|c|c|c|c|c|c|}
\hline \multirow[b]{3}{*}{ Cultivar } & \multicolumn{6}{|c|}{ Natural beetle populations } & \multirow{3}{*}{$\begin{array}{l}\text { Restricted beetle populations } \\
\text { TPAC } \\
2015\end{array}$} \\
\hline & \multicolumn{6}{|c|}{ Site and yr } & \\
\hline & 2015 & 2016 & 2015 & 2016 & 2015 & 2016 & \\
\hline Athena & 192 & $52 \mathrm{bc}$ & $268 \mathrm{bc}$ & $195 \mathrm{a}$ & 334 & $230 \mathrm{bc}$ & 46 \\
\hline Diplomat & 164 & $54 \mathrm{~b}$ & $366 \mathrm{a}$ & $177 \mathrm{a}$ & 491 & $234 \mathrm{~b}$ & 51 \\
\hline Dream Dew & 188 & $49 \mathrm{bc}$ & $227 \mathrm{c}$ & $56 \mathrm{~b}$ & 523 & $296 \mathrm{a}$ & 47 \\
\hline Hales Best & 183 & $47 \mathrm{bc}$ & $199 \mathrm{c}$ & $191 \mathrm{a}$ & 373 & $236 \mathrm{~b}$ & 43 \\
\hline \multirow[t]{3}{*}{ Wrangler } & 183 & $51 \mathrm{bc}$ & $247 \mathrm{bc}$ & $226 \mathrm{a}$ & 395 & $227 \mathrm{bc}$ & 36 \\
\hline & \multicolumn{6}{|c|}{$P>\mathrm{F}$ for cultivar effect } & \\
\hline & 0.27 & 0.0001 & 0.009 & 0.002 & 0.095 & 0.0001 & 0.17 \\
\hline Source (df) & \multicolumn{7}{|c|}{ ANOVA mean squares } \\
\hline $\operatorname{Rep}(3)$ & $26,828.4$ & 777.55 & $4,869.8$ & $9,814.1$ & $109,837.3$ & $15,785.5$ & 269.50 \\
\hline Cultivar (7) & $5,177.7$ & 657.22 & $13,068.0$ & $10,652.0$ & $27,659.5$ & $7,469.8$ & 134.67 \\
\hline Error (21) & $3,786.0$ & 78.90 & $3,507.5$ & $2,136.2$ & $13,449.5$ & 638.6 & 79.87 \\
\hline
\end{tabular}

${ }^{\mathrm{z}}$ Ten striped cucumber beetles per two plants were released under rowcovers immediately after transplanting and allowed to feed for 3 weeks before rowcovers were removed and natural beetle populations allowed to feed. In 2016, lambda-cyhalothrin insecticide applied weekly after rowcover removal reduced beetle numbers to 0 and so data are not reported.

${ }^{\mathrm{y}}$ Means within a column followed by the same letter are not significantly different at $P<0.05$ according to Fisher's protected least significant difference.

SWPAC $=$ Southwest Purdue Agricultural Center; TPAC $=$ Throckmorton/Meigs Purdue Agricultural Center; PPAC $=$ Pinney Purdue Agricultural Center; ANOVA $=$ analysis of variance. 
than 'Dream Dew' and 'Diplomat'. 'Wrangler', 'Hales Best', and 'Savor' had intermediate levels of disease.

In both years at TPAC, bacterial wilt was most severe on 'Dream Dew' and 'Diplomat' (Table 3). 'Superstar' was the least severely affected in both years. Severity of bacterial wilt for 'Aphrodite', 'Athena', and 'Hales Best' was intermediate between 'Superstar' and 'Savor'. Severity of bacterial wilt for 'Wrangler' was between 'Superstar' and 'Savor' in 2015, and between 'Savor' and 'Diplomat' in 2016.

At PPAC bacterial wilt was most severe on 'Diplomat' and 'Dream Dew' in both years, but in 2015, not significantly more severe than on 'Wrangler' or 'Savor' (Table 3). 'Superstar' was the least severely affected by bacterial wilt in both years. Severity of bacterial wilt for 'Aphrodite' and 'Hales Best' was intermediate between 'Superstar' and 'Athena' in 2015. In 2016, 'Athena', 'Aphrodite', and 'Hales Best' were intermediate between 'Superstar', 'Savor', and 'Wrangler'.

When beetle populations were confined on covered plants for 3 weeks after transplanting in 2015, bacterial wilt was most severe on 'Dream Dew' and 'Savor', but not significantly greater than on 'Diplomat' or 'Aphrodite' (Table 3). The disease was least severe on 'Athena' and 'Superstar', but they were not significantly healthier than 'Hales Best', 'Wrangler', or 'Aphrodite'. In 2016, 'Dream Dew' was again the most severely affected, followed by 'Diplomat'. 'Superstar', 'Athena', and 'Hales Best' were the least affected.

Across all site-years, the linear relationship between AUDPC and beetle days was highly significant $(P<0.0001)$ as shown in Fig. 1. Including different intercepts for cultivars significantly improved the model $(P<0.0001)$, but different slopes for cultivars did not improve the fit $(P=0.4851)$. The reduced model including beetle days and cultivar, but not their interaction, had $r^{2}=$ 0.47 and slope $=2.45 \pm 0.315$. Only 'Dream Dew' and 'Diplomat' had intercepts significantly greater than 0 .

Marketable yield. Marketable yield differed among cultivars in both years and at all locations, whether muskmelons were exposed to natural or restricted populations of SCBs (Table 4). When exposed to natural populations, 'Aphrodite' produced among the highest marketable yields in all siteyears. 'Superstar' produced among the highest marketable yields for five of six site-years. Marketable yield for 'Athena' was not significantly different from the highest for four of six site-years. Marketable yield for 'Wrangler' was not significantly different from the highest for three of six site-years. 'Diplomat' and 'Hales Best' produced similar marketable yields, significantly lower than 'Wrangler' in one-third of the site-years. Overall, 'Savor' produced marketable yield numerically, but not usually significantly, lower than 'Diplomat' and 'Hales Best'. 'Dream Dew' had the most variable marketable yield across site-years, ranging from the highest at SWPAC in 2016 to the lowest at PPAC in 2016 and TPAC in both years.

When exposed to restricted populations of SCBs, 'Athena' and 'Superstar' produced the highest marketable yields, but significantly higher than all other cultivars only in 2015 (Table 4). In 2015, 'Wrangler', 'Aphrodite', 'Diplomat', and 'Hales Best' produced marketable yields significantly lower than the top two but not different from one another, whereas 'Savor' and 'Dream Dew' produced no marketable yield. In 2016, 'Wrangler', 'Dream Dew', and 'Aphrodite' produced marketable yield not significantly lower than 'Superstar' or 'Athena'. 'Diplomat' and 'Hales Best' produced marketable yield in between 'Wrangler' and 'Savor'.

\section{Discussion}

These findings showed that in some years, under field conditions where muskmelon cultivars were planted in close proximity (within a few feet of one another), cucumber beetles spent more time on some cultivars of muskmelons than others. In years when cultivars differed, 'Diplomat' and 'Savor' were frequently the most attractive to the beetles, and 'Aphrodite' and 'Superstar' were consistently among the least attractive. 'Dream Dew' showed the most variability in attractiveness: next to the highest in 2016 at PPAC and the lowest in 2016 at TPAC. Variation among cultivars for attractiveness to cucumber beetles was reported by Reed and Stevenson (1985) but they did not report a cultivar ranking. Brust and Rane (1995) found that 'Makdimon' and 'Rocky Sweet' were infested with more SCBs than eight other cultivars, including 'Superstar'. Similar to 'Diplomat', 'Makdimon' and 'Rocky Sweet' are galia-type muskmelons with green flesh and netted rind, suggesting that these types might generally be more attractive to cucumber beetles. However, Brust and Rane (1995) found that the cultivar Galia was more similar to 'Superstar' than to 'Makdimon' and 'Rocky Sweet' in beetle

Table 3. Area under the disease progress curve (AUDPC) values for severity of bacterial wilt for eight muskmelon cultivars exposed to natural or restricted populations of striped cucumber beetles.

\begin{tabular}{|c|c|c|c|c|c|c|c|c|}
\hline \multirow[b]{4}{*}{ Cultivar } & \multicolumn{6}{|c|}{ Natural beetle populations } & \multirow{3}{*}{\multicolumn{2}{|c|}{$\begin{array}{l}\text { Restricted beetle populations }{ }^{y} \\
\text { TPAC }\end{array}$}} \\
\hline & \multicolumn{6}{|c|}{ Site and yr } & & \\
\hline & \multicolumn{2}{|c|}{ SWPAC } & \multicolumn{2}{|c|}{ TPAC } & \multicolumn{2}{|c|}{ PPAC } & & \\
\hline & 2015 & 2016 & 2015 & 2016 & 2015 & 2016 & 2015 & 2016 \\
\hline Aphrodite & $123 b^{x}$ & $154 \mathrm{c}$ & $1,220 \mathrm{bc}$ & $590 \mathrm{~cd}$ & $195 \mathrm{bc}$ & $283 \mathrm{bc}$ & $439 \mathrm{abc}$ & $36 \mathrm{abc}$ \\
\hline Athena & $70 \mathrm{~b}$ & $137 \mathrm{c}$ & $1,463 \mathrm{bc}$ & $633 \mathrm{~cd}$ & $198 \mathrm{~b}$ & $188 \mathrm{~cd}$ & $173 \mathrm{c}$ & $2 \mathrm{c}$ \\
\hline Diplomat & $529 \mathrm{a}$ & $475 \mathrm{a}$ & $2,408 \mathrm{a}$ & $2,414 \mathrm{a}$ & $667 \mathrm{a}$ & $1,236 \mathrm{a}$ & $522 \mathrm{ab}$ & $419 \mathrm{ab}$ \\
\hline Dream Dew & $1,081 \mathrm{a}$ & $358 \mathrm{ab}$ & $2,870 \mathrm{a}$ & $2,885 \mathrm{a}$ & $369 \mathrm{ab}$ & $1,560 \mathrm{a}$ & $718 \mathrm{a}$ & 863 a \\
\hline Superstar & $75 \mathrm{~b}$ & $67 \mathrm{c}$ & $882 \mathrm{c}$ & $456 \mathrm{~d}$ & $74 \mathrm{c}$ & $122 \mathrm{~d}$ & $207 \mathrm{c}$ & 0 \\
\hline \multirow[t]{2}{*}{ Wrangler } & $89 \mathrm{~b}$ & $197 \mathrm{bc}$ & \multicolumn{4}{|c|}{$P>\mathrm{F}$ for cultivar effect } & $329 \mathrm{bc}$ & $18 \mathrm{abc}$ \\
\hline & 0.0001 & 0.005 & 0.0001 & $\begin{array}{l}0.0001 \\
\text { ANOVA n }\end{array}$ & & 0.0001 & 0.006 & 0.05 \\
\hline $\begin{array}{l}\text { Source (df) } \\
\text { Rep }\end{array}$ & $2.9967(3)$ & $18,278(3)$ & $723,038(3)$ & $366,063(3)$ & $\begin{array}{l}\text { squares } \\
4.7284(3)\end{array}$ & $0.1428(3)$ & $10.668(3)$ & $7.5369(3)$ \\
\hline Cultivar & $3.9807(7)$ & $67,682(7)$ & $1,854,745(7)$ & $3,261,011(7)$ & $1.7253(7)$ & $3.1197(7)$ & $167,427(7)$ & $18.0185(6)$ \\
\hline
\end{tabular}

${ }^{\mathrm{z}}$ Disease severity was recorded as the percent of the plot canopy displaying bacterial wilt symptoms; AUDPC values were calculated based on bacterial wilt severity visual assessments taken on four to seven rating dates. Values for SWPAC 2015, PPAC both years and TPAC restricted populations 2016, were natural$\log$ transformed before ANOVA; means presented in the table are back-transformed.

${ }^{\mathrm{y}}$ Ten striped cucumber beetles per two plants were released under rowcovers immediately after transplanting and allowed to feed for 3 weeks before rowcovers were removed. In 2016 only, lambda-cyhalothrin insecticide was applied weekly after rowcover removal to protect plants from insect feeding.

${ }^{\mathrm{x}}$ Means within a column followed by the same letter are not significantly different at $P<0.05$ according to Fisher's protected least significant difference. For restricted beetle populations in 2016, AUDPC for 'Superstar' had variance $=0$ and so that cultivar was omitted from the ANOVA to meet assumptions of equal variance.

SWPAC $=$ Southwest Purdue Agricultural Center; TPAC $=$ Throckmorton/Meigs Purdue Agricultural Center; PPAC = Pinney Purdue Agricultural Center; ANOVA $=$ analysis of variance. 
populations, indicating that not all muskmelons of the galia type are similarly attractive to cucumber beetles.

'Dream Dew' and 'Diplomat' ranked highest for severity of bacterial wilt at all site-years when exposed to natural populations of SCBs. They were also among the top two or three most severely affected cultivars when early season exposure to beetles was restricted by growing under rowcovers and introducing known numbers of beetles. Severity of bacterial wilt increased as beetle days increased for all cultivars, but 'Dream Dew' and 'Diplomat' had more severe bacterial wilt for a given amount of beetle feeding than the other cultivars (Fig. 1). These results suggest that the greater severity of disease observed on these two cultivars may be due in part to greater susceptibility to the disease itself and in part to greater attractiveness to the beetles. 'Dream Dew', in particular, showed high levels of susceptibility in 2016 at TPAC, where it accumulated the fewest number of beetle days but had the highest AUDPC.

In the studies with restricted beetles, where a given number of feral SCBs were placed under rowcovers, 'Dream Dew' and

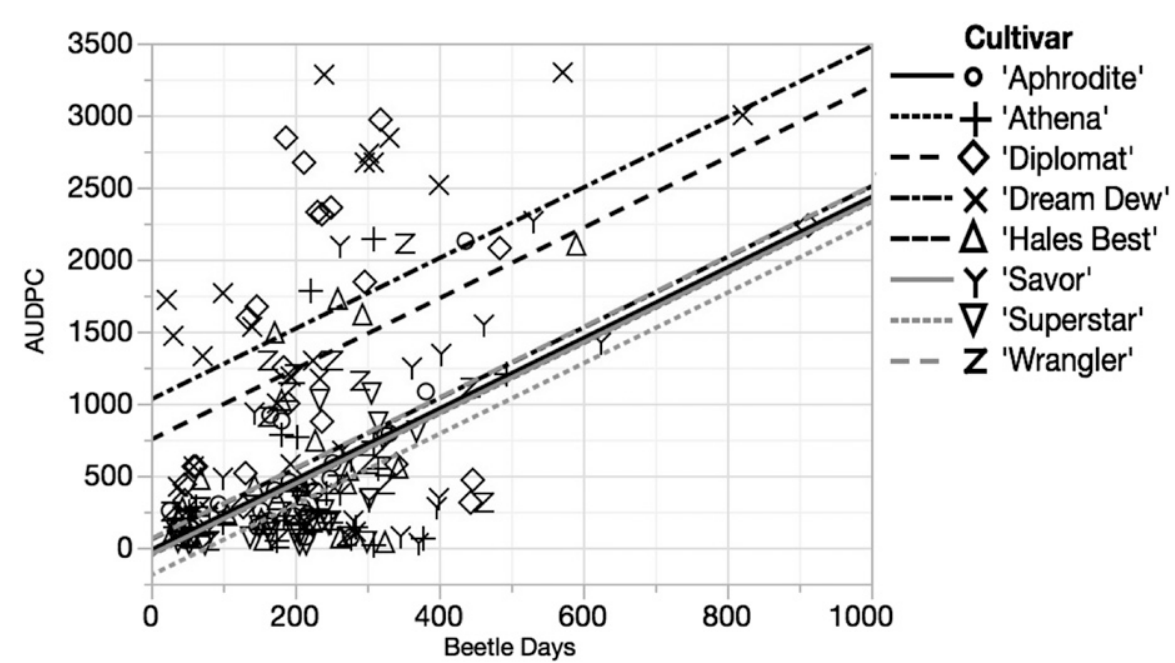

Fig. 1. Area under the disease progress curve (AUDPC) for bacterial wilt vs. beetle days for eight muskmelon cultivars exposed to natural populations of cucumber beetles in 2015 and 2016 at three Indiana locations. Each point represents one experimental unit (plot). Lines represent regression model with a single slope of $2.45 \pm 0.315$ and separate intercepts for each cultivar as follows (estimate $\pm \mathrm{SE}$ ) : Aphrodite: $-17 \pm 134$; Athena: $-51 \pm 138$; Diplomat: $748 \pm 144 *$; Dream Dew: $1027 \pm 140 *$; Hales Best $55 \pm 137$; Savor: $-48 \pm 150$; Superstar: $-192 \pm 136$; Wrangler: $60 \pm 140 . r^{2}=0.47$; Error $\mathrm{df}=183$. *Intercept differs significantly from 0 at $P<0.0001$.
'Diplomat' had AUDPC values on the same order of magnitude in 2015 and 2016, and most other cultivars had AUDPC values 50 or more times higher in 2015 than in 2016 ('Athena', 'Hales Best', 'Savor', and 'Superstar'; Table 3). Although we do not have a clear explanation for these differences, there are plausible explanations. The literature shows that only $1 \%$ to $10 \%$ of feral beetles harbor the bacterium (Brust, 1997; Fleischer et al., 1999). Because we had no way of testing whether each beetle we collected and used was or was not carrying E. tracheiphila, it is possible that given the relatively small number of beetles used in each plot, there may have been differences in the number of infective beetles between cultivars and between years. That would make it more difficult to identify cultivars of different susceptibility and could explain the observed variability in AUDPC values within cultivars in different years.

The difference across years in the studies with restricted beetle numbers could also be explained by factors outside the plant that influence disease transmission. In 2015, two conditions were more favorable for disease transmission. First, no insecticides were applied after rowcovers were removed, so beetles could continue to feed and spread the bacteria. Second, 2015 was wetter during the $21 \mathrm{~d}$ after transplanting when rowcovers were present, with $10.4 \mathrm{~cm}$ of rain measured at the Throckmorton Purdue Ag Center automated station, compared with $4.0 \mathrm{~cm}$ in 2016. Water on leaves facilitates entry of the pathogen into the plant. If, as the results suggest, 'Dream Dew' and 'Diplomat' are more susceptible than the other cultivars, it may also be that, for them, disease development is not affected as much by environmental conditions and presence of beetles on

Table 4. Marketable yield of eight muskmelon cultivars exposed to natural or restricted populations of striped cucumber beetles.

\begin{tabular}{|c|c|c|c|c|c|c|c|c|}
\hline \multirow[b]{3}{*}{ Cultivar } & \multicolumn{6}{|c|}{ Natural beetle populations } & & \\
\hline & \multicolumn{6}{|c|}{ Site and yr } & \multicolumn{2}{|c|}{$\begin{array}{c}\text { Restricted beetle populations }{ }^{\mathrm{z}} \\
\text { TPAC }\end{array}$} \\
\hline & 2015 & $2016^{y}$ & $2015^{y}$ & $2016^{y}$ & 2015 & $2016^{y}$ & 2015 & 2016 \\
\hline Aphrodite & $22.4 \mathrm{ab}^{\mathrm{x}}$ & $23.2 \mathrm{ab}$ & $14.1 \mathrm{a}$ & $10.3 \mathrm{a}$ & $16.5 \mathrm{ab}$ & $7.9 \mathrm{ab}$ & $9.5 \mathrm{~b}$ & $16.0 \mathrm{abc}$ \\
\hline Athena & $15.5 \mathrm{bcd}$ & $26.6 \mathrm{ab}$ & $4.0 \mathrm{bc}$ & $4.2 \mathrm{ab}$ & $14.6 \mathrm{ab}$ & $8.3 \mathrm{ab}$ & $31.4 \mathrm{a}$ & $25.5 \mathrm{a}$ \\
\hline Diplomat & $10.8 \mathrm{de}$ & $14.8 \mathrm{~cd}$ & $0.6 \mathrm{~cd}$ & $0.8 \mathrm{~b}$ & $7.4 \mathrm{~cd}$ & $1.7 \mathrm{c}$ & $6.2 \mathrm{~b}$ & $6.5 \mathrm{bc}$ \\
\hline Dream Dew & $8.2 \mathrm{de}$ & $31.0 \mathrm{a}$ & $0.2 \mathrm{~d}$ & 0.0 & $13.5 \mathrm{bc}$ & 0.0 & 0.0 & $17.7 \mathrm{ab}$ \\
\hline Superstar & $24.3 \mathrm{a}$ & $22.2 \mathrm{~b}$ & $8.6 \mathrm{ab}$ & $8.7 \mathrm{a}$ & $20.2 \mathrm{a}$ & $12.7 \mathrm{a}$ & $28.5 \mathrm{a}$ & $26.3 \mathrm{a}$ \\
\hline \multirow[t]{3}{*}{ Wrangler } & $19.8 \mathrm{abc}$ & $20.3 \mathrm{bc}$ & $8.3 \mathrm{ab}$ & $2.9 \mathrm{ab}$ & $10.8 \mathrm{bc}$ & $5.5 \mathrm{~b}$ & $9.8 \mathrm{~b}$ & $20.1 \mathrm{ab}$ \\
\hline & \multicolumn{8}{|c|}{$P>\mathrm{F}$ for cultivar effect } \\
\hline & 0.0003 & 0.0001 & 0.0001 & 0.02 & 0.0001 & 0.0001 & 0.005 & 0.02 \\
\hline Source (df) & \multicolumn{8}{|c|}{ ANOVA mean squares } \\
\hline Rep & $138.87(3)$ & $1.0473(3)$ & $1.7972(3)$ & $0.8770(3)$ & $113.41(3)$ & $1.1454(3)$ & $188.63(3)$ & $49.825(3)$ \\
\hline
\end{tabular}

${ }^{\mathrm{z}}$ Ten striped cucumber beetles per two plants were released under rowcovers immediately after transplanting and allowed to feed for 3 weeks before rowcovers were removed. In 2016 only, lambda-cyhalothrin insecticide was applied weekly after rowcover removal to protect plants from insect feeding.

${ }^{\mathrm{y}} \mathrm{ANOVA}$ and mean separation for this site-year were performed on square-root transformed data to meet assumption of equal variance; all means presented in the table are untransformed.

${ }^{\mathrm{x}}$ Means within a column followed by the same letter are not significantly different at $P<0.05$ according to Fisher's protected least significant difference. Cultivars with mean $=0$ were not included in ANOVA or mean separation for that site-year because variance $=0$.

SWPAC $=$ Southwest Purdue Agricultural Center; TPAC = Throckmorton/Meigs Purdue Agricultural Center; PPAC = Pinney Purdue Agricultural Center; ANOVA $=$ analysis of variance. 
older plants: severe disease occurs in any case. By contrast, for the less susceptible cultivars, it may be that those factors play a bigger role in determining disease severity. That would explain why some cultivars showed larger differences in AUDPC between years.

Brust and Rane (1995) found the two galia types 'Makdimon' and 'Rocky Sweet' to have greater incidence of bacterial wilt than eight other cultivars, including Superstar, when exposed to natural populations of cucumber beetles, but incidence of bacterial wilt on 'Galia' did not differ from 'Superstar'. These authors did not detect any differences among cultivars in mortality due to bacterial wilt when the pathogen was injected directly into seedling stems, and they concluded that differences in incidence of wilt observed in the field were most likely due to differences in attractiveness of cultivars to cucumber beetles. Reed and Stevenson (1985) also assessed susceptibility to bacterial wilt both by exposing plants to natural populations of cucumber beetles in the field and by inoculating seedlings with the pathogen in the greenhouse. They observed differences in susceptibility among cultivars in both situations. 'Hales Best' was included in their trials and ranked in the middle for susceptibility to the disease, as reported here. One cultivar they used as a susceptible check was 'Charentais Improved'. In the trial reported here, the charentais type 'Savor' was very attractive to beetles but not the most severely affected by bacterial wilt.

The three cultivars that generally performed the best in terms of the least beetle feeding, least disease, and highest yield were 'Superstar', 'Aphrodite', and 'Athena'. These three have been widely grown for commercial production in the Midwest where this work was performed, which is not the case for the other hybrids. It is reasonable to speculate that their lesser attractiveness to beetles and the lower levels of bacterial wilt they experience have contributed to their popularity. 'Superstar' is no longer widely grown for commercial production because the newer cultivars have better postharvest quality.

Today's commercially available muskmelon cultivars differ in attractiveness to SCBs and in susceptibility to bacterial wilt, whether exposed to natural or restricted low numbers of beetles. Together with previous reports, this work suggests that the honeydew and galia-type muskmelons might be more likely to experience severe bacterial wilt than other types, but more cultivars need to be evaluated to determine whether that is the case. Our results also suggest that cultivars widely grown in the Midwest already possess characteristics that reduce losses from the beetles and bacterial wilt compared with others on the market. There does appear to be potential to reduce crop losses from bacterial wilt through improvement of crop genetics, and these results suggest which cultivars breeders could start looking at for resistance traits.

We did not determine whether or to what extent the observed differences in bacterial wilt severity were related to differences in beetle-plant interaction or pathogen-plant interaction. Further research to distinguish the relative importance of these two factors, and their underlying mechanisms, could prove helpful to a crop improvement program.

\section{Literature Cited}

Brust, G.E. 1997. Seasonal variation in percentage of striped cucumber beetles (Coleoptera: Chrysomelidae) that vector Erwinia tracheiphila. Environ. Entomol. 26:580-584.

Brust, G.E. and R.E. Foster. 1999. New economic threshold for striped cucumber beetle (Coleoptera: Chrysomelidae) in cantaloupe in the Midwest. J. Econ. Entomol. 92:936-940.

Brust, G.E. and K.K. Rane. 1995. Differential occurrence of bacterial wilt in muskmelon due to preferential striped cucumber beetle feeding. HortScience 30:1043-1045.

Egel, D.S., R. Foster, and E. Maynard. 2014 Midwest vegetable production guide for commercial growers 2015. Purdue Ext. ID-56.

Fleischer, S.J., D. De Mackiewicz, F.E. Gildow, and F.L. Lukezic. 1999. Serological estimates of the seasonal dynamics of Erwinia tracheiphila in Acalymma vittata (Coleoptera: Chrysomelidae). Environ. Entomol. 28:470-476.

Food and Agriculture Organization of the United Nations (FAO). 2017. FAOSTAT. 15 May 2017. <http://www.fao.org/faostat/en/\#home>.

Foster, R., G. Brust, and J. Palumbo. 2005. Watermelon, muskmelon, and cucumber, p. 199-214. In: R. Foster and B.R. Flood (eds.). Vegetable insect management. Purdue Res. Foundation, West Lafayette, IN.
Horsfall, J.G. and R.W. Barratt. 1945. An improved grading system for measuring plant diseases. Phytopathology 35:655.

Latin, R.X. 1993. Diseases and pests of muskmelons and watermelons. Purdue Univ. Coop. Ext. Serv. BP-44. p. 29

Metcalf, R.L. and R.L. Lampman. 1989. The chemical ecology of diabroticites and cucurbitaceae. Experientia 45:240-247.

Midwestern Regional Climate Center. 2017. Midwest climate: Climate summaries. 13 Dec. 2017. <http://mrcc.isws.illinois.edu/mw_climate/ climateSummaries/climSumm.jsp >

Redman, C.E., E.P. King, and I.F. Brown. 1974 Elanco conversion tables for Barratt-Horsfall rating numbers. Elanco Prod. Co., Indianapolis, IN.

Reed, G. and W. Stevenson. 1985. Bacterial wilt resistance in commercial muskmelon cultivars. Proc. Indiana Acad. Sci. 94:131-140.

Rojas, E.S., J.C. Batzer, G.A. Beattie, S.J. Fleischer, L.R. Shapiro, M.A. Williams, R. Bessin, B.D. Bruton, T.J. Boucher, L.C.H. Jesse, and M.L. Gleason. 2015. Bacterial wilt of cucurbits: Resurrecting a classic pathosystem. Plant Dis. 99(5):564-574.

Shaner, G. and R.E. Finney. 1977. The effect of nitrogen fertilization on the expression of slowmildewing resistance in Knox wheat. Phytopathology 67:1051-1056.

Shapiro, L.R., I. Seidl-Adams, C.M. De Moraes, A.G. Stephenson, and M.C. Mescher. 2014. Dynamics of short and long term association between a bacterial plant pathogen and its arthropod vector. Scientific Rpt. 4:4155.

Smith, E.F. 1911. Bacteria in relation to plant diseases. Vol. 2. Carnegie Inst. of Washington, Washington, D.C.

Stanyard, M.J., R.E. Foster, and T.J. Gibb. 1997. Effects of orchard ground cover and mite management options on the population dynamics of European red mite (Acari: Tetranychidae) and Amblyseius fallacis (Acari: Phytoseiidae) in apple. J. Econ. Entomol. 90:595-603.

USDA-ERS. 2016. Fruit and tree nuts yearbook tables. U.S. per capita use of melons, harvested area, production, cash receipts, shipments, price, supply and utilization, and trade. 25 May 2017. <https://www.ers.usda.gov/webdocs/ DataFiles/54499/FruitYearbookMelons_ETables. $\mathrm{xlsx}$ ? $=42671>$

USDA-NAL. 2017. Agricultural thesaurus and glossary. Muskmelons. 13 Dec. 2017. <http:// lod.nal.usda.gov/nalt/21934>.

USDA-NASS. 2016. Vegetables 2015 summary. 3 Mar. 2016. <http://usda.mannlib.cornell. edu/usda/current/VegeSumm/VegeSumm-0204-2016.pdf>. 